Sanctuary in the Wilderness 
Stanford Studies in Jewish History and Culture e dite д в Aron Rodrigue and Steven J. Zipperstein 


\section{Sanctuary in the Wilderness}

A Critical Introduction to
American Hebrew Poetry

Alan Mintz

STANFORD UNIVERSITY PRESS STANFORD, CALIFORNIA 
Stanford University Press

Stanford, California

(C) 2012 by the Board of Trustees of the Leland Stanford Junior University. All rights reserved.

This book has been published with the assistance of the Lucius N. Littauer Foundation.

Credits appear on p. 52I.

No part of this book may be reproduced or transmitted in any form or by any means, electronic or mechanical, including photocopying and recording, or in any information storage or retrieval system without the prior written permission of Stanford University Press.

Printed in the United States of America on acid-free, archivalquality paper

Library of Congress Cataloging-in-Publication Data

Mintz, Alan L., author.

Sanctuary in the wilderness : a critical introduction to American Hebrew poetry / Alan Mintz.

pages $\mathrm{cm}$.- (Stanford studies in Jewish history and culture) Includes bibliographical references and index.

ISBN 978-0-8047-6293-9 (cloth : alk. paper)

I. Hebrew poetry, Modern-United States-History and criticism. 2. Hebrew poetry, Modern-2oth century-History and criticism. 3. Hebrew language-United States-Revival.

I. Title. II. Series: Stanford studies in Jewish history and culture.

$\mathrm{PJ} 5 \mathrm{O} 24$. $\mathrm{M}_{4} 6$

892.4 'I509973-dc23

2011032254

Typeset by Miles B. Cohen in I0.5/I4 Galliard 
To Susanna, Amira, and Avital, forever 
